\title{
STABILISATION OF HAZARDOUS WASTE ON LANGØYA
}

\author{
Jakob Lindstrøm \\ NOAH, Norsk Avfallshandtering AS \\ Norge
}

\begin{abstract}
NOAH is established to take care of all hazardous waste not accepted by other companies or exported. The Ministry of Environment owns $52 \%$ of the shares in the company. NOAH is located on two sites; A new fuel blending plant in Brevik for organic waste, and a chemical treatment plant for inorganic hazardous waste on Langøya.
\end{abstract}

\section{NOAH}

The Ministry of Environment and 9 major industrial companies established NOAH in 1991. The Government's goal concerning hazardous waste was: Within year 2000 all hazardous waste generated in the country shall be treated in approved treatment and disposal facilities. NOAH is the tool for obtaining this goal. The mandate states that the company shall accept and offer final disposal for all kinds of hazardous waste. NOAH shall offer assistance and consultation concerning hazardous waste minimisation, recycling, and contribute to research and development.

\section{BREVIK SITE}

This plant will produce fuel for a Norcem's cement kiln in Brevik from organic hazardous waste. The design capacity is 30700 tons of liquid, pasty and solid waste. The plant is under construction. It will be operating at the end of 1998 . The kiln has restrictions regarding special elements, but by proper blending it will bum the main part of organic hazardous waste. Some waste will be exported. The total investment is approx. 300 Mill NOK. 


\section{LANGøYA SITE}

The island Langøya was an old limestone resource for a cement company. Two quarries have been excavated during the past 100 years. Both pits, with volume 4 and 5 million $\mathrm{m}^{3}$ below sea level, will be filled up with stabilised inorganic waste.

\section{Neutralisation plant}

This is a chemical treatment plant for inorganic waste. The main process is neutralisation of ferruginous sulphuric acid with limestone, fly ash and lime milk. The residue, the gypsum is pumped to a quarry and settles there. Heavy metals in the waste are incorporated in the gypsum crystal structure and the iron oxide gel. $\mathrm{Fe}^{2+} / \mathrm{Fe}^{3+}$ equilibrium and excess of limestone and lime prevents leakage of heavy metals from the gypsum to the water in the quarry. Other inorganic waste such as metal hydroxide sludge, alkaline waste and heavy metal contaminated soil can also be stabilised by hydrolysis, oxidation, reduction and precipitation. NOAH handles yearly approx. 160000 tons of acids and 25000 tons of fly ash. Fly ash is imported from Denmark, but the capasity permits also import from other European countries. Strict regulations on heavy metals and organic pollutants are set to the surplus water pumped to the sea.

\section{Mercury stabilisation}

A stabilisation method for alkaline batteries containing mercury has been developed. The equipment is now installed. All kinds of household batteries, button cells, alkaline and lithium will be crushed and stabilised chemically. Mercury, zinc and other metals are first chemically fixated as hydroxides or sulphides, then stabilised in concrete. Other mercury waste can be stabilised in the process. Research is going on in order to stabilise metallic mercury.

\section{Solidification plant}

A concrete plant has recently been installed for stabilisation of hazardous waste. Capacity is $15 \mathrm{~m}^{3}$ waste/hour or $50 \mathrm{~m}^{3}$ concrete. This plant shall stabilise coursegrained waste or waste not properly stabilised in the other processes.

\section{Other services}

Contaminated soil is received and landfilled as inert waste in a special section of the quarry. A soil-washing unit will fractionate soil contaminated with leachable contaminants or organic pollutants. The contaminated sludge will be composted or treated separately, while the cleaned soil is used to return the island for rehabilitation of the island.

NOAH receives cyanides and metal cyanide complexes for oxidation and chemical stabilisation of the remaining metals.

\section{Total investments}

A total of 250 Mill NOK has been invested on Langøya since 1991. 